\title{
Features of Ultrasonic Waves Influence on Different Types Biological Tissues
}

\author{
I.M. Lukavenko
}

\author{
Sumy State University, 2, Rymsky-Korsakov St., 40007 Sumy, Ukraine
}

\author{
(Received 01 June 2020; revised manuscript received 15 October 2020; published online 25 October 2020)
}

\begin{abstract}
The mechanisms of ultrasonic waves influence on biological tissues with the use of visualization of processes in tissue under the ultrasound action are studied in the work. It is shown that the reflection and absorption of ultrasound by tissues depend on their structure, properties and frequency of ultrasonic vibrations. Focused ultrasound with an intensity of $100-1000 \mathrm{~W} / \mathrm{cm}^{2}$ is used for surgical operations which allows local destruction in the deep structures of tissues without damaging the surface layers. The basis of the physiological and therapeutic effects of ultrasound is the mechanical, thermal and physicochemical effects caused by it, the relationship between which depends on the intensity of exposure and the conditions of its implementation. An important role is played by the neuro-reflex mechanism of influence on the body. Ultrasound accelerates the processes of regeneration and repair, restoration of nerve fiber conduction in peripheral nerve injuries, resorption of infiltrates, traumatic edema, exudates and hemorrhages (primary effects), has anti-inflammatory, analgesic, antispasmodic, metabolic, hypotensive, antihypertensive effects and regional blood flow (secondary effects). It is established that strong absorption of ultrasound is observed on the borders of tissues that have different acoustic properties (skin/subcutaneous tissue, fascia/muscle, periosteum/bone). The ultrasound absorption changes markedly when the condition of the tissue changes due to the development of pathological processes in it.
\end{abstract}

Keywords: Ultrasonic waves, Biological tissue, Surgical operations, Adipose, Glandular and muscle tissue.

DOI: 10.21272/jnep.12(5).05005

PACS numbers: $42.55 . \mathrm{Wd}, 42.62 . \mathrm{Be}$

\section{INTRODUCTION}

Different types of radiation are used in electronics, sensor technology and medicine: laser, ultrasonic, highfrequency etc. (see, for example, [1-4]). Under the ultrasonic waves influence, any surface (metal, glass, wood, plastic) can be turned into a sensor panel. In medical practice, ultrasonic oscillations with a frequency of 800 to $3000 \mathrm{kHz}$ are used, in ultrasound surgery from 20 to $100 \mathrm{kHz}$. The ultrasound absorption by pathological tissues depends on their acoustic properties and the frequency of ultrasonic oscillations. The ultrasound intensity with a frequency of $800-900 \mathrm{kHz}$ is reduced by about half in soft tissues at a depth of 4 $5 \mathrm{~cm}$, and with a frequency of about $3000 \mathrm{kHz}-$ at a depth of $1.5-2 \mathrm{~cm}$.

Adipose tissue absorbs ultrasound about 4 times, muscle -10 times, and bone -75 times stronger than blood. The strongest absorption of ultrasound is observed at the borders of tissues with different acoustic properties (skin/subcutaneous tissue, fascia/muscle, periosteum/bone). The absorption of ultrasound changes noticeably when the condition of the tissue changes owing to the development of a pathological process in it (edema, infiltration, fibrosis, etc.).

At the boundary of two media, not only the direct but also the reflected wave is absorbed. An air layer of $0.01 \mathrm{~mm}$ almost completely absorbs ultrasound, so when carrying out medical procedures to create an airless space, contact media are used. The speed of propagation of ultrasound is maximum in solid media and is minimum - in gaseous. Ultrasound causes pressure drops -compression and liquefaction of the medium. The pressure difference can reach $260 \mathrm{kPa}$. At high intensity of ultrasound, cavitation can occur i.e. the rupture of tissues and fluid with the formation of cavities. The basis of emitters and receivers of ultrasonic waves used in medical equipment is either piezoelectric or magnetostrictive effect.

For surgical operations, focused ultrasound is used which allows to locally destroy deep structures without damaging the surrounding tissues (the ultrasound 100$1000 \mathrm{~W} / \mathrm{cm}^{2}$ ). In surgery, traumatology and orthopedics, special ultrasound instruments are used to dissect and «weld» bones, soft tissues and organs, perform reconstructive and plastic surgery, prevention and treatment of purulent infection.

The aim of the work was to study the biological and physical mechanisms of the influence of ultrasonic waves on biological tissues.

\section{EFFECTS IN BIOLOGICAL TISSUES UNDER THE INFLUENCE OF ULTRASOUND}

The bases of the ultrasound therapeutic effect are the mechanical, thermal and physicochemical effects caused by it, the relationship between which depends on the exposure intensity and its conditions [4]. An important role is played by the neuro-reflex mechanism of influence on the body.

Mechanical action of ultrasound. The mechanical action is due to high-frequency oscillations that are transmitted to tissues in contact with the emitter. The result is microvibration, which stimulates the functions of cellular elements and the whole cell, leads to increased permeability of cell membranes, rupture of weak bonds, reduced cytosol viscosity, changes in microcirculation, loosening of connective tissue, acceleration of diffuse processes, increased sensitivity of cells to physical and chemical agents. There is a rupture of lysosomes, the release of enzymes, and, as a result, the activation of metabolic processes.

Thermal action of ultrasound arises as a result of transformation of a part of the absorbed energy of 
ultrasonic waves into heat. Tissue temperature rises by $1{ }^{\circ} \mathrm{C}$ which is accompanied by changes in enzyme activity, the rate of biochemical reactions, diffusion processes and local circulation. Characteristically, the formation of heat occurs only at the interface. Heat accumulates at the boundaries of different environments (the interface of tissues with different acoustic resistance), in the tissues most absorbing ultrasound energy (nerve, bone, collagen-rich fascia) and in places with insufficient blood supply.

Non-thermal action of ultrasound. For the occurrence of cavitation, the presence of cavitation nuclei, microscopic gas particles is required. Cavitation embryos naturally get into body fluids, it is assumed that various hydrophobic impurities stabilize them in the fluid. At a high amplitude of the acoustic field, the cavitation nuclei begin to vibrate and approach the resonant value due to direct diffusion and coalescence (fusion) of bubbles. The resonant radius of the bubbles increases with decreasing ultrasound frequency, respectively, at low frequencies the effects of cavitation are stronger.

Physical and chemical action of ultrasound is determined by mechanical resonance, under the influence of which the motion of molecules accelerates, their decomposition into ions intensifies, the isoelectric state changes, new electric fields are formed, free radicals and various products of sonolysis of biological solvents appear. Electronically excited states appear, lipid peroxidation is activated, enzymatic activity and mitochondrial activity change, physicochemical and biochemical processes in tissues are stimulated, metabolism is activated, biologically active substances are released from stem cells, and histamine under the influence of ultrasound.

Ultrasound stimulates tissue respiration and oxidative processes in tissues, affects carbohydrate, fat and mineral metabolism. These changes largely determine the stimulating effect of ultrasound on the processes of physiological and reparative regeneration. Ultrasound accelerates the processes of regeneration and re-repair, restoration of nerve fiber conduction in peripheral nerve injuries, resorption of infiltrates, traumatic edema, exudates and hemorrhages (primary effects), has antiinflammatory, analgesic, antispasmodic, metabolic, hypotensive effects, increases the adsorption properties of the skin and regional blood flow (secondary effects) [5, 6].

Consider the mechanisms of biological action of ultrasonic waves. The flow of molecules across the cell membrane is described by Fick's first law:

$$
\vec{j}=-D \frac{d c}{d x},
$$

where $D$ is the diffusion coefficient, $d c / d x$ is the substance concentration gradient.

Under stationary conditions, $d c / d x$ can be replaced by the ratio of the difference in concentrations $c_{1 l}-c_{1}$ to the thickness of the membrane:

$$
\vec{j}=-D \frac{c_{1 l}-c_{1}}{l}=P\left(c_{1}-c_{1 l}\right),
$$

where $P=D / l$ is the membrane permeability coefficient, $l$ is the membrane thickness.
Under real conditions, the solution layers directly adjacent to the membrane are practically not mixed, therefore, the concentration of molecules in these layers can differ significantly from the concentration of similar molecules in the volume. The thickness of these layers varies from 1 to $100 \mu \mathrm{m}$ and depends on the surface properties and the intensity of mixing of the solution.

The set of membrane with diffusion layers can be considered as an effective membrane, whose thickness is determined by the formula:

$$
l_{\text {eff }}=l+\Delta x_{1}+\Delta x_{2},
$$

where $\Delta x_{1}$ and $\Delta x_{2}$ are the thicknesses of the diffusion layers on both sides of the membrane.

The flow through the membrane is described by the equation

$$
\vec{j}_{e f f}=\frac{D_{e f f}}{l_{e f f}}\left(c_{1}-c_{l 1}\right)=P_{e f f}\left(c_{1}-c_{2}\right),
$$

where $D_{\text {eff }}$ is the generalized diffusion coefficient, $P_{\text {eff }}$ is the permeability, $c_{1}$ and $c_{2}$ are the concentrations of molecules.

Under the influence of ultrasound, $\Delta x_{1}$ and $\Delta x_{2}$ are significantly reduced as a result of intensive mixing of the solution by microflows. Accordingly, $l_{\text {eff }}$ decreases and the flow of substances through the membrane increases [5, 6].

By normal diffusion through cell membranes, a variety of compounds penetrate into the cell. In addition to water, these are uncharged molecules of many water-soluble substances, including many complex drugs. At heating due to the transition of the energy of ultrasound into heat, the temperature difference between the center of the cell and its periphery at the intensity of ultrasound $300 \mathrm{~W} / \mathrm{cm}^{2}$ according to calculations is $10^{-3} \mathrm{~K}$, and the temperature gradient is $2-5 \mathrm{deg} / \mathrm{cm}$ [6].

In summary, we can determine the following mechanism of ultrasound action on cells of biological tissues (Fig. 1). Physicochemical ultrasonic effects in the environment (mechanical, thermal, electrical, chemical) change the permeability of cell membranes (acceleration of diffusion, change in the efficiency of active transport, violation of membrane integrity) $\rightarrow$ violation of cell composition and extracellular environment $\rightarrow$ change in the rates of enzymatic reactions in the cell (small activation and predominant suspension of enzymatic reactions in enzyme concentrations of substances) $\rightarrow$ development of reparative reactions in the cell associated with the synthesis of other substances (ribonucleic acid synthesis and new enzymes produced by the cell to compensate for the lack of deficiency in the products of enzymatic reactions) $\rightarrow$...

From the analysis of this scheme (Fig. 1), it follows that specificity in the action of ultrasound on biological systems is a change in the microenvironment of cell membranes, which leads to disruption of the transfer of substances across membranes. Further chain of processes can also be initiated by other physicochemical factors that lead to similar disorders, in particular, to an increase in the permeability of cell membranes. 


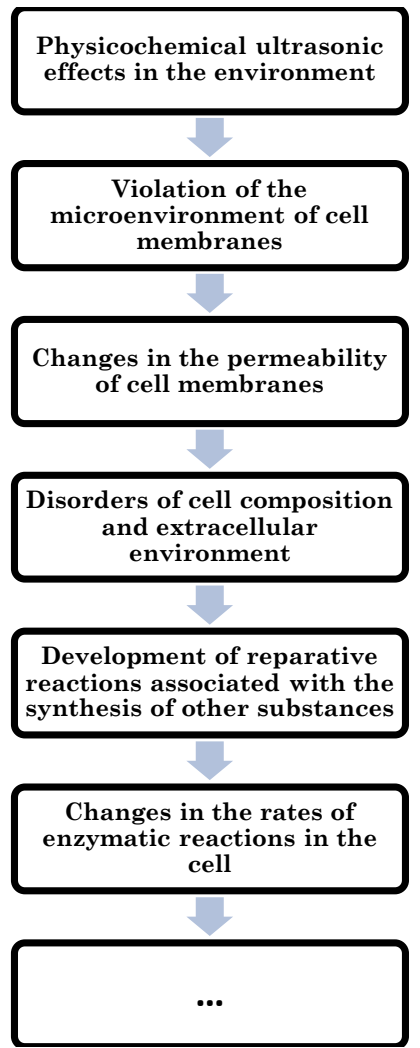

Fig. 1 - The mechanism of action of ultrasound on cells

\section{METHODS AND RESULTS OF THE EXPERIMENT}

To study the influence of ultrasonic waves on different types of biological tissues, we used a portable ultrasound machine Samsung Medison with high image quality, color Doppler SonoAce R3. The Samsung Medison electronic system has the function of restoring the three-dimensional structure of tissue surfaces (magnification, rotation, etc.). SonoView is a system of archiving and further viewing static and dynamic images (database of images). DICOM is a system for network integration with PACS-systems (for example, for archiving or printing ultrasonic echograms on the equipment of other manufacturers of medical equipment); packages of ultrasonic diagnostic programs.

The tissues were exposed using the OLYMPUS SonoSurg G2 ultrasound system, which allows precise ultrasonic coagulation and cutting during the operation (Fig. 2)

Fig. 3 shows examples of sonograms that visualize changes in tissues under the influence of focused ultrasonic radiation. We emphasize that the nature of tissue destruction under the action of ultrasonic surgical instruments significantly depends on their elastic properties and homogeneity.

Adipose tissue has a higher reflection coefficient ( $K=10 \%)$ compared to other soft tissues. The energy of the ultrasonic wave that crosses the adipose tissue/soft tissue boundary is less than after crossing the boundary with other soft tissues, and along with the defocusing of the ultrasound beam in adipose tissue, this leads to a decrease in signal levels from structures located at great depths.

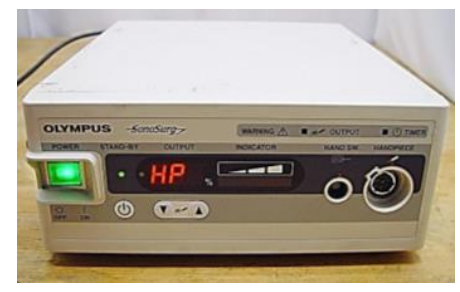

Fig. 2 - Ultrasonic device OLYMPUS SonoSurg G2

If the environment in which the propagation of ultrasound takes place has viscosity and thermal conductivity, then when the ultrasonic wave propagates, it is absorbed, i.e., as it moves away from the source, its energy decreases. Most of the energy absorbed by the tissue is converted into heat, a smaller part causes irreversible structural changes. It is known [7] that $2 / 3$ of the ultrasound energy is absorbed at the molecular level and $1 / 3$ at the level of microscopic tissue structures. The absorption also depends on the frequency of the ultrasonic oscillations - the absorption increases rapidly with increasing frequency.

Theoretically, the absorption is proportional to the square of the frequency. But the absorption of ultrasound in biological tissues does not obey the general laws for homogeneous environment.

In biological tissues, there is not a quadratic but a linear dependence of absorption on frequency, which is explained by the heterogeneity of tissues and the different degree of absorption of ultrasound (Fig. 3).

For example, the least absorption is observed in the fat layer and almost twice as much in muscle tissue.

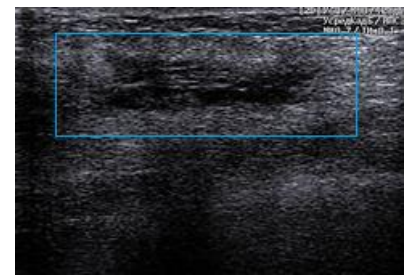

a

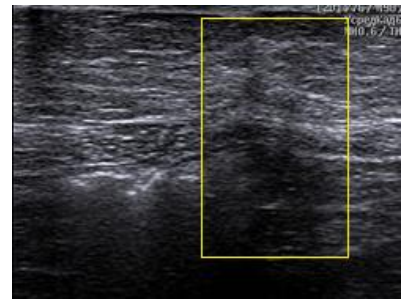

$c$

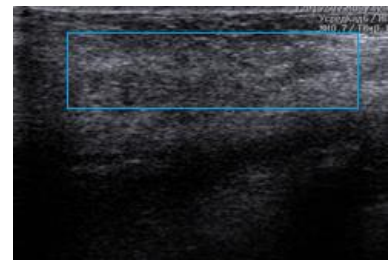

$\mathrm{b}$

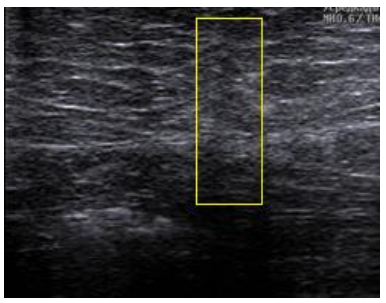

d
Fig. 3 - Visualization in the form of sonograms of the influence of ultrasound on tissues: a - anechoic strip of fluid as a consequence of the action of the ultrasonic wave on the glandular tissue of the breast; $b$ - barely noticeable hypoechoic strip in the postoperative area 10 days after exposure to an ultrasonic scalpel (tissue regeneration processes); $\mathrm{c}-$ hypoechoic area as an influence of ultrasound on the muscles; $d$-regeneration of muscle tissue after surgery

\section{CONCLUSIONS}

1. The paper considers the mechanism of focused ultrasound action on biological tissues. It is established 
that the absorption of ultrasound by tissues depends on their acoustic properties and the frequency of ultrasonic vibrations. The strongest absorption of ultrasound is observed at the boundaries of tissues that have different acoustic properties. The absorption of ultrasound changes markedly when the condition of the tissue changes due to the development of a pathological process in it.

2. It is shown that focused surgical ultrasound is used for surgical operations, which allows to carry out local destruction in deep structures without damaging the surrounding tissues (ultrasound intensity reaches
100-1000 W/cm ${ }^{2}$ ). The use of focused ultrasound allows to locally affect the surface and deep structures of the body by creating local, controlled hyperthermia without overheating the surface tissues.

3. Specificity in the action of ultrasound on biological systems is the change in the microenvironment of cell membranes, which leads to disruption of the transfer of substances across membranes. The subsequent chain of processes can also be initiated by other physicochemical factors that lead to similar disorders, in particular, to an increase in the permeability of cell membranes.

\title{
REFERENCES
}

1. Stanley B. Barnett, Hans-Dieter Rott, Gail R. ter Haar, Marvin C. Ziskin, Kazuo Maeda, Ultrasound Med. Biol. 23 No 6, 805 (1997).

2. S.I. Protsenko, L.V. Odnodvorets, I.Yu. Protsenko, Springer Proc. Phys. 156, 345 (2015).

3. I.M. Lukavenko, V.V. Andryushchenko, A.V. Yazykov, J. NanoElectron. Phys. 10 No 6, 06031 (2018).

4. I.M. Lukavenko, J. Nano- Electron. Phys. 11 No 6, 06015 (2019).

5. R.L. Nichols, S. Florman, Clin. Infect. Dis. 33 No 2, 84 (2001).

6. Z. Izadifar, P. Babyn, D. Chapmanz, Ultrasound Med. Biol. 43 No 6, 1085 (2017)

7. I.M. Lukavenko, V.V. Andryushchenko, A.V. Yazykov, J. NanoElectron. Phys. 11 No 3, 03008 (2019).

8. V.R. Drier, M. Yao, C.J. Miller, Wound Rep. Reg. 19, 475 (2011).

\section{Особливості впливу ультразвукових хвиль на біологічні тканини різних типів}

\section{I.M. Лукавенко}

\section{Сулський державний університет, вул. Рилського-Корсакова, 2, 40007 Сули, Украйна}

\begin{abstract}
У роботі вивчені механізми впливу ультразвукових хвиль на біологічні тканини з використанням візуалізації процесів в тканині під дією ультразвуку. Показано, що відбиття і поглинання ультразвуку тканинами залежить від їх структури, властивостей і частоти ультразвукових коливань. Для хірургічних операцій використовують фокусований ультразвук інтенсивністю $100-1000 \mathrm{BT} / \mathrm{cm}^{2}$, який дозволяе проводити локальні руйнування в глибинних структурах тканин без пошкодження поверхневих шарів. Основу лікувальної дії ультразвуку становлять викликані їм механічний, тепловий і фізико-хімічний ефекти, співвідношення між якими залежить від інтенсивності впливу і умов його проведення. Важливу роль відіграе і нервово-рефлекторний механізм впливу на організм. Ультразвук прискорюе процеси регенерації і репарації, відновлення провідності нервових волокон при травмах периферичних нервів, розсмоктування інфільтратів, травматичних набряків, ексудатів і крововиливів (первинні ефекти), має протизапальну, аналгетичну, спазмолітичну, метаболічну, гіпотензивну, фібринолітичну і бактерицидну дії, підвищуе адсорбційні властивості шкіри і регіонарний кровоток (вторинні ефекти). Установлено, що сильне поглинання ультразвуку спостерігаеться на межі тканин, які мають різні акустичні властивості (шкіра/підшкірна клітковина, фасція/м'яз, окістя/кістка). Поглинання ультразвуку помітно змінюеться при зміні стану тканини в зв'язку з розвитком в ній патологічних процесів.
\end{abstract}

Ключові слова: Ультразвукові хвилі, Біологічна тканина, Механічний, тепловий і фізико-хімічний ефекти, Хірургія. 